\title{
The study of the open-type multiple appraisal models in British and American Literature Course from the respective of general education
}

\author{
Haiyan Liao \\ Department of Foreign Languages, Hunan University of Science and Engineering, Yongzhou, \\ 425199, China
}

Keywords: General education. British and American literature. Open type. Multiple appraisal models. Study

\begin{abstract}
British and American Literature Course is one of the compulsory courses for English majors. From the respective of general education, English teachers should continuously analyze and study the open-type multiple appraisal models in British and American Literature Course, dig deep into teaching focuses as well as making all-round improvements of teaching quality and level. The article mainly analyzes the features of the open-type multiple appraisal models in British and American Literature Course from the respective of general education. In addition, it sets forth that under this education model and education concept, teachers should take the initiative to recognize the existing problems, strengthen their own learning, improve their teaching ability and level, pay attention to students' personality developments as well as stressing on quality-oriented education. Finally, aimed at the existing problems in the teaching of British and American Literature Course, it provides some suggestions for English teachers to carry out educational practical activities.
\end{abstract}

\section{Introduction}

Our social system reforms further, promoting the continuous reform and innovation of education in China. From the respective of general education, English teachers should actively adapt to the current situation of the education development, dare to face the challenges from the education reform, carry forward teachers' fine traditions, establish the concept of life-long learning and insist on education positions. At present, the open-type multiple appraisal model in British and American Literature Course is a newly advocated education mode aimed at improving teachers' teaching quality and teaching level under the new situation. There is great effect and significance in studying and analyzing this kind of education mode which can help teachers find problems, actively look for solutions to problems, and ultimately achieve ideal teaching effect.

\section{General education course system}

With the arrival of a new era, China's higher education turns from the elite education to the mass education gradually which brings college English teachers new challenges in carrying out teaching practical activities. The English major curriculum is paid more and more attention to the popularization; curriculum teaching is no longer limited to the content of the textbook, but set to the continuous professional developments. In the practical activities, teachers should make use of the modern cyber source to collect and arrange plentiful extracurricular resources for courses. In addition, teachers should enrich teaching knowledge and contents, striving for the realization of mass education. Especially in the perspective of general education, the teaching contents are very rich, involving many subjects and levels, including people and things, people and people as well as people and nature, etc.

From the respective of general education, British and American Literature Course is divided into the formal curriculum and informal curriculum. The formal curriculum mainly focus on the students' basic-skill assessments, including students' language applying skills, writing skills and other skills , which is the basic teaching task of British and American Literature Course teaching as the core component of the general education. In addition, the informal curriculum mainly requires teachers to 
develop curriculum knowledge, cultivate students' ability in other aspects, such as skills of information collection, collation and application, and extend teaching to the outside of the classroom. With the deepening of education reform, teachers teaching British and American Literature Course must put this teaching concept into practice, pay attention to teaching innovation, change traditional teaching concepts and methods, and constantly improve the open-type multiple appraisal models.

\section{The open-type multiple appraisal models}

The open-type multiple appraisal model is a newly advocated teaching concept and teaching system opposite the traditional examination-oriented education system in our country. In practical teaching, teachers should carry out the teaching concept and teaching system and they must understand the core concept of this teaching mode. The open-type multiple appraisal model requires teachers to insist on treating every student with an open eye, focus on the overall quality of students, especially the cultivation of students' all-round development, promote students' individual thinking ability, using their own subjective initiatives to improve their self-directed learning and expansion ability.

In the British and American Literature Course teaching, the open-type multiple appraisal model is a new image of school-based assessments. In the traditional student evaluation model, teachers pay great attention to students' learning results, focusing on the pursuit of "quantitative change ". This kind of teaching concept and the evaluation method seriously violates China's currently advocated concept of quality-oriented education. Therefore, the open-type multiple appraisal model is an innovation and expansion of the traditional evaluation mode with the researchers' continuous summary of experience in order to highlight the quality evaluation. It pays attention to the development of students' personality and independent thinking, trying to carry out the curriculum practice exploration in the text connection, etc. This educating and teaching evaluation model can achieve great practice effects and cultivate all-round and open-type English professional talents for the society.

\section{The application status of the open-type multiple appraisal model in British and American Literature Course from the respective of general education}

\section{School-based evaluation is like "wearing new shoes to walk old paths" -- stick to the beaten track despite all the new phraseology}

With the development of the curriculum reform, many advanced teaching concepts and teaching modes are provided for teachers to carry out teaching activities, however, China's education system has been ingrained so that the execution of many new teaching concepts and teaching modes is very low. How should teachers apply and implement new teaching concepts in the teaching practical activities has become highly valued by the academic staff. At present, during the teaching of British and American Literature Course, teachers still pay much attention to the knowledge on textbook as well as the professional knowledge and they are still the subject of class activities because the teachers must use the limited teaching time to teach English students more knowledge. In this situation, students have few chances to participate in the practical activities of class. A lot of teachers assess and evaluate their students mainly according to students' final-exam grades, while ignoring the students' daily performances. The phenomenon of "wearing new shoes to walk old paths" seriously restricts the teaching quality of British and American literature course; students cannot obtain the all-round developments.

\section{Teaching evaluation model falls behind}

The traditional teaching evaluation is blindly based on the assessment of students' professional competences; students' mastery of professional knowledge is the core of general education. But this kind of educational concepts also requires teachers to pay attention to the cultivation of the non-professional skills. However, China's traditional education system affects teachers' teaching thinking. During the teaching activities, teachers pay no attention to the personality development of 
students and students seldom act on their own in the class. Also, teachers have no time and energy to observe the students' personality and strength, which results in the implement failure of teaching students in accordance of their aptitude. Under this long-time teaching mode, students' own learning passion will gradually disappear and turn into a passive acceptance of curriculum knowledge. Meanwhile, Students firmly believe in the teachers' teaching practical activities without the spirit of exploration and innovation. The traditional closed and single evaluation mode is not conducive to the development of students' thinking and learning potential, which disenables students to fit in their operating posts faster and better after their entry into the society with strong professional knowledge, but insufficient adaptive capacity for new social environment, or non-compliance in the quality levels of other aspects.

\section{The application strategies of the open-type multiple appraisal models in British and American Literature Course from the respective of general education}

\section{Change the teaching concepts}

With the traditional teaching concept unable to adapt to the requirements of the development of the new era, teachers must implement and innovate the multiple appraisal models. At first, they should change their own teaching concepts in order to lay the foundation for the teaching practical activities. From the respective of general education, the teachers are required to enrich teaching contents, pay attention to the cultivation of students' overall quality and ability, and promote the all-round development of students. Therefore, teachers should firstly make the main body of teaching practical activities clear. From the perspective of students, teachers should consider the actual needs of students, especially the special group who are about to enter the society for job hunting. In the face of fierce competition in the social market, only students with strong comprehensive abilities can get an ideal job for themselves. Teachers should pay more attention to the combination of market and social demand for talents, point out the key points of British and American literature course, make use of information resources, and constantly enrich and develop the teaching contents. At the same time, teachers must change the evaluation concepts and methods, pay attention to not only students' final-exam grades, but also students' practical and participating abilities during the daily learning process. The teachers should use the open-type multiple appraisal models to help students build up confidence as well as establish a long-term interest in the study of British and American literature course. The teaching concept change is a new requirement from the perspective of general education for the teaching practical activities. In order to implement the open-type multiple appraisal models, teachers must establish a new teaching concept and thinking, and then promote the teaching innovation through the ideology's influence on their teaching activities.

\section{Pay attention to the students' personality developments}

Paying attention to the students' personality developments is the core of the open-type multiple appraisal models. In the traditional teaching model, teachers focus on the mastery assessment of students' professional knowledge, while ignoring their personality development. In the new situation, teachers should set up an all-round development concept and in the practical teaching activities, teachers should adhere to the "student centered", help students find out their own personality and strength, and take advantages of the practical activities to develop students' strengths. As in British and American Literature Course teaching, teachers can carry out role play or inquiry teaching activities. Firstly let students reorganize the text in advance to form a small drama with the inserts in the textbook, and then rehearse in groups. In the process of practice and demonstration, students can not only learn professional knowledge combined the situation, but also apply English professional knowledge to practice. Through the practical activities, students will learn replace thinking, find out their advantages and shortcomings and have self-directed learning. In addition, the group work can promote the exchanges and learning among students, train students' adaptation ability to the teamwork, cultivate students' all-round development, and make multiple assessments of students.

\section{Highlight quality-oriented education}


Highlighting quality-oriented education requires teachers to pay attention to the overall assessments of students in the daily teaching. The "quantitative change" is no longer the only content of teaching evaluation, but "qualitative change" is of more importance. At the same time, teachers should carry out formal and informal British and American Literature Course teaching. In the formal teaching, teachers should pay attention to the cultivation of students' professional skills as well as their moral quality, combining the ideological education with the teaching. British and American Literature Course cultivates students' application competence, and the ultimate goal for students is to communicate with the others. If the student's own overall quality level is not up to the standard, in the actual work and life, it is very difficult to meet the job requirements. Without the team spirit and self-learning ability, they cannot survive in the team better. Therefore, highlighting quality-oriented education requires that teachers encourage their students to participate in the practical activities, help students to find their own problems by observing students' daily performances, teach students in accordance of their aptitude, conduct "one to one" teaching method, guide students to establish correct learning concept and ideology, and culture the overall quality of students. Highlighting quality-oriented education is a newly advocated requirement of the open-type multiple appraisal models for teachers to carry out practical teaching activities. Especially in the teaching of British and American Literature Course, more and more attention should be paid to the cultivation of students' cultural quality and humanistic spirit. Meanwhile, teachers should use the modular examination to make comprehensive evaluation of students, and attach importance to students' performances by using a comprehensive evaluation method which combines the quality levels with the professional skills. Thus, it can fully develop the potential and learning motivation of students, cultivate their innovative spirit, practical ability and expressive ability, and finally promote their healthy overall development.

\section{Carry out the practical teaching}

The practical teaching trains the students' practical ability and it's also an important approach and method extending the curriculum teaching to the practical teaching as well as fully exercising and cultivating students' overall skills in the practical teaching. Teachers teaching British and American Literature Course can make use of the multimedia teaching resources to organize students to collect a large amount of extracurricular information resources, exercise their information collection ability and enrich teaching contents which is also a new requirement of British and American Literature Course from the respective of general education. The teachers divide the students into groups before the class. With the advantage of the network technology, the students provide the teaching contents for their teacher. Then, the group members present a class lecture which will be collectively evaluated by the students and the teacher according to the different tasks and performances in the practical activities. The teachers should do the daily assessment registration, reconstruct "students' growth record bag", put the open-type multiple appraisal models into practice, innovate this evaluation system continuously, and further improve the quality and level of the teaching practice.

\section{Conclusion}

In summary, the open-type multiple appraisal model is an innovation of the traditional education pattern and concept whose main purpose is to improve the teachers' teaching quality, motivate teachers' lifelong learning, give full play to the important role of teachers during the teaching of British and American Literature Course. In addition, Teachers should pay more attention to the teaching reflection in the daily teaching, the cultivation of students' creativity, the development of the students' thinking ability, and the creation of a lively atmosphere in the class for students. Finally, teachers should adhere to the "student-centered" teaching philosophy, regard developing the potential of students as the highest goal in teaching, gradually cultivate students' expansion ability and level, guide them to apply the knowledge into the real life and work, and bring up more English professional talents for the China's international economic and trade exchanges. 


\section{Acknowledgments}

This article is one of the phased objectives under the provincial educational reform subject, 2013 - The Study of Appraisal Models in British and American Literature Course from the Respective of General Education (no. Hunan Educational OneNote [2013] 223-425). And it's also one of the phased objectives under the school-level subject, the study of the high-quality curriculum reform from the Respective of General Education-taking" Selected readings in British and American literature” course teaching for example(no. [2012]17-17).

\section{References}

[1] Shen Qi: Research-based University General Education on Foreign language Education Mode and Creative Talent Education , Modern Education Science, 2008(01).

[2] Fu Hongxun: Thought on the Bilingual Education in Independent Colleges , Industrial \& Science Tribune, 2011(07).

[4] Chen Hongying: Practical Writing Course-the Exploration and the Experience of the Reformation "Based on the Curriculum Design and Development of the Work Process”, Knowledge Economy, 2011(08).

[5] Zheng Hua: E-commerce Professional Bilingual Curriculum Reform in the Local Higher Education Institution, Journal of Yangtze University(JCR Social Science Edition) , 2009(04).

[7] Chen Muhong: Thoughts on College Chinese resent Situation and the Countermeasures in Higher Vocational Colleges, Journal of Guangdong Vocational and Technical College, 2008(03).

[8]Luo Chuanxiang: Educational Reform and Practice of Competence-based Practical Writing Course in Vocational Colleges , Career Horizon, 2009(09). 